\title{
Development Strategy of Markisa Agroindustry in Increase Gowa Society Income at South Sulawesi
}

\author{
Aminuddin \\ Faculty of Economy, University of Muslim Indonesia, Makassar
}

\begin{abstract}
The aim of this research are (1) to know the horticulture of markisa as the best product in Gowa regency and its contribution towards PDRB, (2) to know the component of transactional cost existing in the interaction of markisa agro industry and design the strategy in developing the passion fruit agro industry in Gowa regency. The obtained data are analyzed by using the area analysis, base analysis and transactional cost analysis. The results showed that (1) the horticulture of passion fruit in Gowa regency has potency to be the superior product; (2) the contribution of markisa agroindustry in Gowa regency towards the receiving of PDRB was low. (3) the component of transactional cost in the activity of passion fruit agro industry were transactional cost and contract agreement; (4) strategy in developing the markisa agro industry in Gowa regency conducted in two ways (a) the improvement of road facility and infrastructure and controlling relating with trade traffic due to main component constructing the interaction of passion fruit agro industry was interactions cost $(b)$ the giving of production facility aiming to minimize the appearance of transaction cost relating with the contract enforcement namely war material quality based on the industrial need (c) to bureaucracy the accessibility in giving the business credit (d) institutional synergy to enforce the cooperation between top and down line.
\end{abstract}

Keywords: Agroindfustry, Transaction Cost, Institutional Synergies.

\section{Introduction}

A national development planning for prioritize development in economics, with a heavy connectedness between industry and agriculture by improving the quality of human resources. In order to realize it, and orientation done is balanced economic structure between industry and agriculture both viewed in terms of value added and absorptions of labor.

Industrial agriculture is an important factor in the economy for several reasons: (1) Agroindustries directly related to the activities of production to meet the basic needs of mankind, namely the need for food and clothing, (2) open up jobs outside farming, (3) increase the value added of agricultural products, (4) increase the income of farmers, and (5) is a non-oil and gas product revenue for the consumption market of the world, especially in countries that are emerging such as Indonesia (Saragih, 1992). In Indonesia, the agricultural sector and the industrial sector have linkages and mutual support. In this thought-provoking landscape, one of potential agricultural commodities in industrial agriculture is the passion fruit.

Markisa (Passifloraceae) is one of the plants have high potential to be cultivated. Despite not fruit native nusantara, this kind of plant has really gone places to a number of areas Lampung, some of South Sumatera and slightly in East Java. There are several advantages plant of the latin american, first, its technically having a certain bigness as a kind not spoiled. It means with treatment, markisa capable of growing normal, even grown in less productive land. Second, the fruit is still wide open market. Markisa having the content of vitamin A, B6 and C. It often consumed in the form of material drink a pack syrup, coktail, and pollen. The demand for the markisa in addition to come from domestic market and also emanated from the middle east, japan and taiwan. Yet another feature, production levels capable of being reached 30 tons per hectare in the period from one period of growing season. But to reach a maximum of that, needed adequate equipment.

However, Agroindustry and production markisa in Sulawesi Selatan now has not found the source of raw materials, in meaning quantity and quality throughout the year to support the production, hence required on good cooperation and mutual benefit between farmers markisa, brokers and industry markisa. Besides that farmers has constraint in terms of capital so cannot afford the seed and fertilizer is a faced recently, so also partnership and it has been done since 1995 until now but not in conformity with expectation and the fact facing farmer.

Area development agroindustry markisa (horticulture) in Gowa as an effort to reduce inequalities around economic growth then one alternative offered to the public, according to character culture and the condition of the land is the development of strategic commodity can contribute to growth agroindustry. Considering agroindustry type that developed in the area is relatively good, it has to priority about growth that capable to capture the double effect (multiplier effect). 
Agroindustry markisa can drive economic growth and income enhancement of society in general and especially for farmers. Thus the commodity agro-industry implemented to enhance competitiveness, and added value so will create jobs, enhance investors who engages in an activity and agro-industry in turn to increase public welfare

\section{Methodology}

This research is a descriptive study using questionnaire patterned and structured according to the needs of the data as well as referring to subject and title research (Singarimbun dan Effendi, 1986). Descriptive methods aimed at producing picture sistimatically, factual and accurate concerning the facts and the relationship between phenomena to get the truth. Comparative method used to analyze factor cause of the phenomena and compare fenomena-fenomena certain where data is collected after all occurrences finished lasting (Nazir, 1989).

A method of analysis which consist of (1) Territory analysis (sector base ); (2) the descriptive analysis agro-industry markisa; and (3) operationalize of variable.

\subsection{Overview of Agroindustry of Markisa and Labor at Gowa \\ III. Result And Discussion}

Passion fruit production in Gowa Regency is one of the results of agricultural production potential, rich and very useful to the region and is expected to be able to create jobs that are able to absorb manpower. Processing industries markisa that exists at this moment in the county industrial gowa either engaged in making pulp and making syrup current majority of its employees of elementary, are graduates sltp and agro-industry smas so the potential to develop markisa is ery accurate in addition to being able to provide value added agricultural dai passion fruit is also capable of absorbing labor with low human resources

\subsubsection{Location of Passion fruit (Markisa) at South Sulawesi}

Analysis of the passion fruit production center in the province of South Sulawesi is used to know the passion fruit production base, distribution and characteristics of its contribution as a passion fruit producers in support of South Sulawesi area income mainly Gowa.

Based on the calculation LQ analysis markisa in south sulawesi with use, production indicators the district is knowable wilayah the basis of production between 23 district scattered throughout south sulawesi region during the past five years markisa base in south sulawesi undergoing change.

In 2004 to 2008 District base in South Sulawesi passion consists of three districts, namely Tator, Sinjai, Gowa. Such districts can meet the needs for the County's own passion as well as several other areas. The regency can fulfill a need for a district own markisa and several other areas. In 2004 until 2008 district not markisa production base in south sulawesi is Palopo, Luwu, North Luwu, East Luwu, Wajo, Soppeng, Bone, Bulukumba, Selayar, Bantaeng, Jeneponto, Takalar, Makassar, Maros, Pangkep, Barru, Parepare, Sidrap, Enrekang, Pinrang. It is due for production horticultural (besides markisa) in kabupaten-kabupaten is also high that can balance markisa production

The area that became the passion fruit production base in 2005 and 2006, there are 3 passion fruit production base County in 2004 remains the region of passion fruit base in South Sulawesi Province. The amount of passion fruit production base county in the province of South Sulawesi, undergone a change. District sinjai can no longer be district basis in 2007 since the value of lq smaller than one. The regencies which become area base starting in 2004 to with the year 2008, namely Tator and Gowa. Sinjai for in 2004, 2005, 2006 and 2008 became the basis for the year 2007 was not a region of Sinjai District base, sinjai Regency is caused due to no longer being able to produce such a passion in other counties.

\subsubsection{The role of Markisa in supporting economy of South Sulawesi}

The role of passion in support of the activities of agroindustries in the province of South Sulawesi, specially Gowa can be known by looking at the development or growth of the region as a result of activities in the sector of the base. Moreover, it can also be seen cruising the propagation and influence base sector directly or indirectly to the activities of agroindustries in the province of South Sulawesi

\subsubsection{Basic Service Ratio (BSR) Markisa}

Analysis of Basic Service Ratio (BSR) is used to describe a power base of the sector areas support the activities of agro-industries in South Sulawesi. The value obtained from the result analysis BSR show comparisons between the production of activities of the base of a territory and production in the activities of a service to other areas (Local). BSR value greater than one means base sector markisa able to support economic development in the province bsr sulawesi-selatan and if the value of less than or equivalent to one, and base sector markisa incapable support the economy of sulawesi-selatan. 
Basic Service Ratio (BSR) passion fruit/Markisa in South Sulawesi-based on the analysis of the calculation is greater than one, meaning the sector passion fruit base supports the economy or agro-industries in South Sulawesi. In 2004 - 2008 BSR more than one, means that Markisa support the economy or agro-industry in Sulawesi Selatan. BSR value greater than one have the meaning that one part used to meet the needs and the development of the sector basis while the rest of their needs and the development of the non the base.

Based on analysis of research, obtained the result that value BSr markisa in sulawesi-selatan during the period research fluctuate. The highest BSR value retrieved in 2006 that is equal to the 212,017. Value of the BSR has the meaning that the 212 part of passion fruit production is used to meet the needs of the development of the base and parts used to 0,017 cater to the development of the non-base.

Fluctuations of the increasing in the value of the index BSR caused by the increase or a decrease in demand over fluctuations markisa itself. Meanwhile, demand over markisa it can be derived from in the county of itself as well as from the district of another. Hence, to keep index value BSR always greater than 1, needed to focus sustainability production markisa. If value index bsr always greater than 1 and markisa will significantly contributed to farmers markisa and society in the region.

Throughout the year 2004 up to 2008, the value of the index BSR in South Sulawesi still tending to high that can be concluded that in 2004, 2005, 2006, 2007, 2008, markisa capable of being significantly contributes in the form of added value against the region of the base, so that in future needs to be enhanced again production markisa in the south sulawesi in the region at the base and non the base

\subsubsection{Regional Multiplier (RM) Markisa}

An analysis of the regional mutiplier (RM) was a continuation of analysis BSR, where the result analysis can be detected a relationship directly or indirectly from the existence of the base.

Based on the result analysis RM, can be known that the value of RM for markisa in the sulawesi-selatan remained in a range of the value of 3,501 until 1,011. RM markisa in the sulawesi-selatan value is greater than one. Based on these calculations, the results can be interpreted as that the existence of the base sector of passion fruit can support the economy for South Sulawesi Province itself and give impact multipliers for other areas or in other words that one part is used for the base and the rest is pernambahan to the effects of non-base.

The average value of RM is greater than one can also be said that the efforts of Markisa in South Sulawesi give impact multiplier. The impact can include the direct effect as work force absorption to venture; and impact indirect as increasing income and work force absorption through its other related business markisa as agro-industry that uses markisa as feedstocks (syrup markisa), activities transportation increases and impacts other inflicted.

\subsubsection{Problem Identification of Agroindustry of Markisa in Gowa}

To know the problem agro-industry markisa in gowa South Sulawesi, then required an observation in order to get an image of the level of farmers, business communities, until the arena market. In this case, then the troubles in exploring garoindustri markisa this differentiated into two things, namely the problem in the aspect of business investment (the upstream level/husbandman) and the problem in the aspect of the commercial distribution as well as institutional business.

\subsubsection{Investment Problem}

Business investment problem is the problems which accounted for at the level of below (the upstream level/husbandman). The problem in the domain of this is more focused about constraint cultivation and technical aspects, such as the production of management and human resources (husbandman), capital, as well as supporting such as infrastructure facilities and infrastructure.

In the level of business investment, the problem in aspect that do not can be released is from the character of the product itself. Refer to analysis of the aspect of business investment acquired some of the issues are markisa that is seasonally, properties of plants susceptibility of disease, limited husbandman; long distances in the processing industries, and productivity gap between the region. Of this problem, impact on inefficiency of production low plant, the prevention of disease and not we varieties the lowlands so influential on production imbalance and low competitiveness

It can be said, there is a perception that the threat of the development of the cultivation of passion fruit at the level of farmers. In particular with regard to the threat that the selling price fluctuating, the spread of diseases such as root rot, inefficiency cost of production, as well as other commodities rising plateau more than doubled profits to plant passion fruit (disincentive for farmers). Specifically to productivity, also be a serious threat when productivity only provides a level that is most likely (production possibility frontier ) in accordance with technology perfunctory. So, in the context of technological innovation production markisa who is able to improve efficiency in the production of constituted the domain the government to provide it. 
In terms of environmental aspects of business, the heaviest of the problem is the high of transaction cost, vulnerability $3,821.63$ hulu until hilir also reflected from the poor coordination between farmers and processing industries. Where farmers suffered a loss in at the peak of the harvest season, while at the same time parties processing industry gain advantage of low prices

But when outside the harvest, the industry faces the problem of scarcity of supply. In this case, virtually between two institutional level, still fragile especially at a farmer. The commercial distribution problems exacerbated by sometimes emergence assymetric information between farmers and pengepul, either sub-district level and district on the issue price and places where real farmers can sell markisa with higher

When viewed, the institutional at the level of farmers have the meaning important as strategic points (entry point) in moving a system of agribusiness, in rural areas. It' s still dealing with diverse empirical research stating that farmers are in a powerless. It' s still dealing with diverse empirical research stating that farmers are in a powerless. In an empirical manner, the fate of farmers always in the condition of being weak and depressed. Deere \& Janvry in yustika, 2009, at least identify seven a mechanism that make farmers still far from a condition and prosperity, especially that which occurred in a developing country, namely rent in labour services, rent in kind, rent in cash, appropiation of surplus value via the wage, appropiation via prices, appropiation via usury, peasant taxation.

Based on research, in the study diverse weakness husbandman can be categorized by several factors included in the farmers

a. The lack of consolidation of farmers in one container to unify economic motion in any chain of agriculture, from pre production to marketing

b. The lack of production collectivication, is production planning collectively to determine the pattern of, the quantity and the cycle of production collectively

Further, based on behavioral conduct and performance, There are several factors that is thought to cause disparitas especially in regard to information prices in any industry markisa supply chain (Firdaus et.al, 2008).

a. ome businessman who dominant in the commercial distribution of trade between region, often to perform also the doing of vertical integration of start usahatani to trade

b. Among dominant businessmen also terindikasikan horizontal integration occurs, where interconnected amongst them in particular business which is packed with kinship

c. The existence of a Union of entrepreneurs that are generally followed by entrepreneurs of the course to allow for building agreements

\subsection{Development Strategy of Agroindustry Markisa in Increasing Societies Income}

3.2.1 Empowering strategy of institution of commercial distribution agro-industry markisa supply chain

In developing markisa agro-industry in district gowa needs good strategy from the government to agroindustry and the parties themselves. The headwaters, necessary is integration esp. introduksi from government in line, being conformable so that the final objective is equally policy can be manifested.

Propelling farmers or farmer groups markisa in this absolutely necessary to change the system institutional existing in agriculture, especially that has limitations the resources and market access. Basically group farmers is element function as unit unity business farmer can manage agriculture in cooperative (Amang\& Sawit, 1999).

1. Improving the competitiveness of aquaculture capacity and passion fruit, with specification

a. Extensification of effort in improving the productivity of the passion fruit;

b. Improved quality of human resources and passion fruit farmers through training;

c. business funding or financing Facilitation cultivation for farmers;

d. increasing aid facility and infrastructure to the concept of management together through association; and

e. technological development processing

2. Strategies for empowerment and institutional arrangement in supply chain of Commerce, with specifications

a. institution strengthening farmers markisa through association;

b. strengthening cooperation between farmers association markisa

c. the formation and strengthening concept partnership business by several parties related;

d. facilitation provision of information service market and technology improvement;

In addition to development strategies in the upper level, then you need to do is reform the institutional level in the lower reaches. In this regard, the development of sub-systems of marketing supposed to do through two main activities; (1). encourage the development of domestic markets and outside areas, (2). Develop distribution system markisa. The targets achievement of grooves the commercial distribution of markisa it is actually increasing bargaining position of farmers 


\subsubsection{Industrial Agriculture Policy Reform Strategies of Markisa}

Based on derived of transaction cost element in the field and find some strategies that could be developed for markisa agroindustry in Gowa. First, strategies to overcome transaction costs related to the cost of monitoring with regard to the stability of the supply of raw materials and the quality of the crops is through good policy steps and intensification of efforts on extensification. Second, directly motivate to an offender agroindustry processing markisa. Motivation the result interaction someone with a given situation faced. Differences force motivation shown someone in dealing with a given situation compared with others who face the same situation. Third, maximize the role of diverse departement of associated, especially departement of industry and trade.

Some actions that can be performed by the Government, is

a. Provide assistance machinery or equipment.

b. Provide commodity passion fruit as a result of study of industrial core competence areas.

Of the various existing problems in markisa agroindustries, especially investment business and commerce, the strategy can be done actually concerns two things. First, absolute done is institution strengthening upper until lower level. However, more urgent is institution strengthening level farmers as producer the fruit. Nevertheless, the more urgent is the strengthening of institutional arrangements at the level of farmers as producers of passion fruit. Development the farmers through institutional agriculture/the farmers is an well planned effort to empower done consciously and earnest through joint ventures farmers to fix diversity system economy rural communities. The empowerment of farmers will be adjusted with a deal that was formulated jointly. With a high participation of institutional sense, is expected to join the farmers have from the public on all of the activities carried out will be too high.

In identifying the role of institutional farmers markisa, then there are diverse profit if institution strengthening farmers markisa can prioritized, namely;

1. As a mediator. The Mediator here can be seen when the farmers group passion fruit serves as a liaison/agency gateway (the gateway institution) between farmers and third parties such as cooperatives, Government, or other elements

2. The farmers can serve as coordinator. Coordinator can serve when members not understand / digest information, as an alternative kepengolaan resources, and as management pre-prosperous production and post production

3. Farmer groups as forming the strong social capital. Strong social capital will automatically influence on economic performance of its members ( economics performances

in addition, it should be taken is policy reforms that is impartial management of commercial especially with regard husbandman markisa welfare system. In this regard should be created a need to create a better relations contract between parties farmers and processing industries, either in terms of its price, quantity, and the quality.

The problems that faced by farmers is related to the problems of the age of the plant and the spread of disease. It is clear that the policy needed is related to changes in techniques of cultivation. Excess production and jeleknya the relationship between production and marketing is a common problem.

If policy on closed supply chain system that is controlled by a party can be applied, processing industry then all parties will gain an advantage, parties farmers will benefit by the implementation of the contract prices and production that is better, while the industry pengolah benefit by the stability of prices and supply certifiable

While the policy that needs to be avoided is the policy in an effort to revitalize the market asymmetry due to the nature of the reactive but not planned properly. It is tend to the failure of the market (market failure) should be borne by society because of imperfect market competition. The form or structure of the industries that build oligopoly or monopoly set up by a number of manufacturers or are likely to have a single power and bargaining position (bergaining position) a very strong would be very harmful to the welfare of the community particularly farmers ' livelihoods.

Need is also emphasized the role of Government, where the Government's role in Commerce in line with growing market processed product passion fruit itself. This is interesting considering the passion fruit market naturally will experience growth in line with the pattern of the economy from an agricultural bergesernya in the direction of the pattern of the economy that is increasingly characterized by industrial pattern.

\section{Conclusion}

Based on the problem and research objectives stated earlier as well as the discussion of the findings, the situation in the previous chapter then in this study can be obtained some conclusions as follows:

1. Horticulture markisa district gowa potentially as superior products because the location quotient ( lq ) of 2004 until 2008 larger than one. Besides consideration broad- land and potentially large enough to be developed 
2. Transaction cost element in activity agroindustry of markisa in gowa are elements of transportation costs and the enforcement agreement. For it to reduce cost transportation can be done through improving infrastructure transportation and elements transaction cost enforcement agreement happened because farmers doing an outside agreement mengakibabkan an accepted price by farmers lower than the market price.

Strategy in the development of agro-industry markisa in the county of gowa can be done by means of

a. Repairing facilities infrastructure of roads and supervision that deals with traffic trade because a principal constituent the emergence of interaction in agro-industry markisa is transportation costs

b. Granting the means of production to farmers which aims to minimize the appearance of transaction cost that deals with enforcement agreement namely quality of raw materials, according to need industry

c. the government needs to provide facilities in acquiring business credit that is getting cheaper. This will encourage aksebilitas credits for agro-industry

\section{Conclusion}

1. The government needs to take notice of transaction cost element that develops in the activities of the mountainous district, agro-industry markisa gowa for an element of the cost of this can affect behavior and the decision of economic agents in agro-industry to gain inputs required

2. The need for improving services and attention from the government in embodying development strategy gowa agro-industry markisa in the county

3. The Government and the farmers need to increase markisa productivities as the leading commodities in the Gowa in efforts to increase contributions to the acceptance of markisa agroindustries to GDP

\section{Referrences}

[1] Saragih, Bungaran, 1992, Agroindustri Sebagai Sektor Terdepan yang Memimpin Dalam PJP II, dalam Dinamika Pemikiran tentang Pembangunan Pertaniann Perhepi, Jakarta

[2] Nasir. 1989. Metodologi Penelitian. Jakarta: Erlangga.

[3] Abdul Wahab, 1997 Analisis Kebijakan: Dari Formulasi ke Imflementasi Kebijakan Negara. Jakarta Bumi Aksara

[4] Ahmad, Abbas. 2007. Pengembangan Agroindustri Unggulan Daerah di Kabupaten Belu, Nusa Tenggara Timur, (Online), (http://www.smecda.com, diakses tanggal 19 Februari 2012)

[5] Aaker, David A. 1995. Developing Business Strategies, Fourth Edition, Canada : John Wiley \& Sons, dimodifikasi.

[6] Andreng Purwanto. 1990. Pengembangan Agroindustri sebagai Penggerak Pembangunan Desa, Yakarta

[7] Amang, B. dan M.H. Sawit. 1999. Perdagangan Global dan Implikasinya pada Ketahanan Pangan Nasional. Agro-Ekonomika No. 2 Tahun XXVII: 1-14. Perhepi. Jakarta.

[8] Arifin, Bustanul. 2005. Ekonomi Kelembagaan Pangan. Jakarta: Anggota IKAPI.

[9] Arsyad, Lincolin. 1999. Pengantar Perencanaan dan Pembangunan Ekonomi Daerah. Edisi Pertama, Yogyakarta: BPFE

[10] Asosiasi Pemasar Hortikultura Jawa Timur. 2000. Konsep Terminal Hortikultura (Auction Market). Studi Potensi dan Peluang Usaha Agroindustri dan Agribisnis di Jalur Lintas Selatan Kabupaten Banyuwangi. Jember

[11] Austin, J.E. 1981. Agroindustrial Project Analysis. EDI Series in Economic Development. Washington, D.C. USA

[12] Badan Pusat Statistik. 2004. Indikator Industri Kecil dan Kerajinan Rumah Tangga 1996-2001, Jakarta

[13] Badan Pusat Statistik. 2007. Sulawesi Selatan Dalam Angka. Sulawesi Selatan

[14] Basalamah, Salim. 2003. Optimalisasi Aktivitas Agroindustri Markisa Di Kabupaten Gowa

[15] Bird, R.M. 1990. Intergovernmental Finance and Local Taxation in Developing Countries; Some Basic Considerations for Reformers, dalam Smith, B. (Ed), 1990, Public Administration and Development, Vol. 10 No. 3 (July-September 1990). London: John Wiley \& Sons

[16] Departemen Perindustrian dan Perdagangan. 2005 Program dan Strategi Pembangunan Industri Kimia. Agro dan Hasil Hutan: Direktorat Jenderal Industri Kimia, Agro dan Hasil Hutan, (IKAH) 2005 - 2009, Jakarta.

[17] Dinas Perindustrian dan Perdagangan Kabupaten Gowa . 2007. Laporan Akhir Pengembangan Kompetensi Daerah Dalam Rangka Peningkatan Daya Saing Kawasan Timur Indonesia. Dinas Pertanian Taman Pangan Kabupaten Gowa.

[18] Elly, Hadidjah Femi, 2008, Dampak Biaya Transaksi Terhadap Perilaku Ekonomi Rumah Tangga Petani Usaha Ternak Sapi Tanaman Di Sulawesi Utara, Disertasi, Sekolah Pascasarjana Institusi Pertanian Bogor, Bogor 